\title{
Pisacano Leadership Foundation Selects Its 2002 Scholars
}

The Pisacano Leadership Foundation, the philanthropic arm of the American Board of Family Practice, recently selected its 2002 Pisacano Scholars. These 4 medical students follow in the footsteps of 35 scholar alumni who are practicing physicians and 19 current scholars who are attending medical school or are enrolled in family practice residencies. Since its founding in 1993, the Pisacano Leadership Foundation has selected students who exhibit the qualities that typify the vision and legacy of Nicholas J. Pisacano, MD, the founder and first executive director of the ABFP. Each Pisacano scholar has shown the highest level of scholarship, leadership, character, interpersonal skills, and community service. The following are summaries of the academic and personal accomplishments of each member of the Pisacano Class of 2002 Scholars.

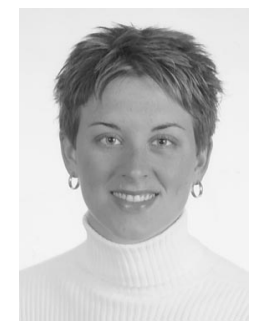

Ariel Carls is a fourth-year medical student at Mayo Medical School. She graduated summa cum laude from the University of Minnesota-Duluth with a bachelor of arts degree in English and a minor in chemistry. Ariel has been a member of Phi Kappa Phi for the last 8 years. While in college she received the Louis A. Roberg Scholarship in recognition of strong academic achievement and a commitment to community service. She was a co-founder of the UMD campus chapter of Habitat for Humanity International (HFHI) and helped to motivate a group of students to participate in the HFHI Collegiate Challenge Program, which included extensive fundraising and organizational efforts leading up to a week-long service trip. Ariel has continued her involvement with HFHI during medical school by volunteering at local building sites. Before beginning medical school, Ariel worked at Grace House in Minneapolis as a lead caregiver. As part of this position, she was re- sponsible for providing direct, daily care to patients living with human immunodeficiency virus infection and acquired immunodeficiency syndrome, as well as encouraging self-care and independence. In addition, she has served as a mentor through the YMCA Y Mentors Program for the last several years.

Ariel has maintained an excellent academic record in addition to her leadership roles at Mayo. Earlier this year, she was named one of two AAFP James G. Jones, MD, scholars and was selected to attend the American Medical Student's Association Political Leadership Institute. Ariel, along with her co-leaders of the Mayo Family Medicine Interest Group, was a recipient for 2 consecutive years of the National Family Medicine Interest Group Network Program of Excellence Award given by the American Academy of Family Physicians. This award is in recognition of outstanding efforts to promote the specialty of family practice on the medical school campus and within the community. Ariel was the 2001-2002 student director of the Minnesota Academy of Family Physicians (MAFP) and is currently in her second year of service on the MAFP academic affairs committee. She is the student member of the AAFP Commission on Public Health, in which she represents the student membership of the AAFP as the commission drafts and updates academy policy regarding public health, discusses and plans future projects, and makes recommendations regarding public health-oriented resolutions.

Ariel has a strong interest in Spanish and is currently pursuing further language training in preparation for spending part of her fourth-year rotations working with Spanish-speaking populations in St. Paul and in Ecuador. She intends to practice in an underserved area after completion of her family practice residency, possibly through placement with the National Health Service Corps or Indian Health Service. 


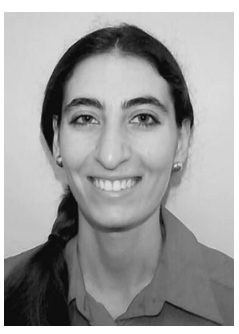

Anna Flattau is a fourth-year medical student at Harvard Medical School. She graduated summa cum laude from New York University with departmental honors in European studies. Anna was a National Merit Scholar, a Presidential Merit Scholar, and the speaker at the NYU Phi Beta Kappa induction ceremony. In addition to her academic accomplishments, she was active in her community while in college. She volunteered with several organizations, including the Worker's Rights Center, where she provided advice and Spanish-English translations to workers with occupational grievances, and the Centro de Educacion de Trabajadores, where she taught English to low-income immigrants. She also assisted in patient education sessions at the St. Luke'sRoosevelt HIV Clinic and worked at the Eastern Paralyzed Veterans Association, where she wrote a policy paper on changes in the Department of Veteran Affairs and their effects on spinal cord injury patients.

Upon graduation from college, Anna received a Fulbright Fellowship to study for a master's degree in health promotion at the London School of Hygiene and Tropical Medicine, from which she graduated with distinction in 1999. Anna has continued to excel as a medical student. After her first year at Harvard, she received the Paul Dudley White/Andrew Sellard Traveling Fellowship to spend 9 weeks with government health services in the Highlands of Chiapas, Mexico, surveying the experiences of tuberculosis patients. Most recently, she spent 2 months at the Centro Latinoamericano de Perinatologia in Montevideo, Uruguay, where she helped analyze an international database examining risk factors for postpartum hemorrhage. As a family physician, Anna hopes that her clinical experiences with patients will inform and guide her work in public health research and policy.

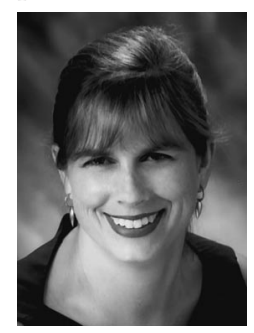

Kristine McCoy is in her final year at the Stanford University School of Medicine. Her undergraduate years were also spent at Stanford, where she received a degree in human biology. Since college, Kristine has been actively engaged in community health and primary care activities. After graduation, she volunteered for a year with the AIDS program of the Department of Health Services in San Mateo County, Calif. Kristine then received her master's in public health from the University of California-Los Angeles School of Public Health. While at UCLA, she worked as a research assistant for the Institute for Social Science Research and the Los Angeles Public Health Foundation Women, Infants and Children (WIC) Program, and as a research associate for the UCLA School of Public Health in the Division of Population and Family Health. In addition, she was an instructor for The Princeton Review SAT preparatory course and the America Achievement Academy.

Before medical school, Kristine spent several years with the Office of Disease Prevention and Health Promotion of the US Public Health Service, US Department of Health and Human Services, in a variety of capacities, including working on national health care reform efforts and serving as the coordinator of child, adolescent, and school health programs. Since beginning medical school, she has continued in her strong leadership capacity. She serves as the principal investigator for a study on health-related quality of life through the Center for Primary Care and Outcomes Research, teaches in the undergraduate health policy program, and is the co-founder and a fellow of the Public Service Medical Scholars Program at Stanford. She also oversaw the pilot fellowship program until the hiring of permanent staff and currently serves on the selection committee for community-partnership research, the faculty-student steering committee, and the executive committee.

During the past year Kristine was instrumental in leading a group of students who confronted the leadership at Stanford for its plan to dissolve family medicine as an independent academic entity at the school. This student group played an important role in changing the course of these events, with the result that the family medicine program is now involved in a renewal of its mission at Stanford. As a future family physician and member of the $\mathrm{Na}$ tional Health Service Corps, Kristine plans to use her education and experience in population and family health from a public health perspective to practice in a comprehensive community health center, to remain active in health policy issues, and to engage in the civic life of her community. 


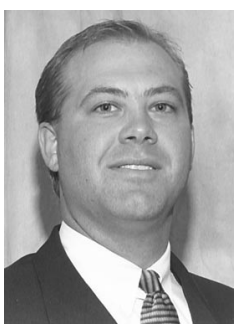

Michael Schafer is a fourthyear medical student at the University of Kentucky College of Medicine. He graduated with a bachelor of science degree in biology from Northern Kentucky University. After graduation, Michael developed and led a children's ministry for 1 year with his local church, which is still in effect. As an ordained minister, Michael oversaw the worship, education, development, and functioning of the church. Before beginning medical school, Michael then worked for 5 years as a senior research associate with Proctor \& Gamble, where he was the co-inventor on four patents.

As a medical student, Michael has continued his community activities, academic excellence, and strong leadership. Michael was the recipient of several scholarships, including an academic excellence scholarship and scholarships to attend the AAFP National Conference and the Society of Teachers in Family Medicine annual predoctoral education conference. Recently, he was nominated for election into the Alpha Omega Alpha honor medical society and was also awarded the College of Medicine Beale Primary Care Scholarship. Locally, Michael facilitated the development of the mission statement, vision, and critical success criteria for the Kentucky Free Health Clinic Association.
Through Michael's leadership, student committees were formed, approximately $\$ 70,000$ in grants and private donations was raised, and services were expanded at the Salvation Army student-run free clinic. He is currently leading an evidence-based project to characterize the demographics and medical needs of the clinic population. The newly reorganized clinic has peaked strong interest in volunteerism at the University of Kentucky. For his efforts, Michael was awarded the community service award from the University of Kentucky College of Medicine.

In addition, Michael assisted the University of Kentucky residency program director in developing a community service learning elective, the first of its kind for the university. As co-developer and course assistant, Michael also helps obtain speakers and schedule students to work at the Salvation Army student-run free clinic. He has authored several presentations including co-authoring a proposal to the Kentucky legislature last year to obtain funding for a family practice faculty member to work with the medical students at the student-run free clinic and the Kentucky Free Health Clinic Association. Upon completion of residency, Michael envisions practicing close to his hometown in northern Kentucky, taking an active role in all aspects of his community. He plans to be an advocate for health care and an educator to patients, other physicians, and health care students. 